\title{
Fixation and sequestration of carbon dioxide by copper(II) complexes
}

\author{
SETHURAMAN MUTHURAMALINGAM ${ }^{\mathrm{a}}$, MARAPPAN VELUSAMY ${ }^{\mathrm{b}}$ and \\ RAMASAMY MAYILMURUGAN ${ }^{\mathrm{a}, *}$ \\ ${ }^{a}$ Bioinorganic Chemistry Laboratory/Physical Chemistry, School of Chemistry, Madurai Kamaraj University, \\ Madurai, Tamilnadu 625 021, India \\ bepartment of Chemistry, North Eastern Hill University, Shillong, Meghalaya 793 022, India \\ E-mail: mayilmurugan.chem@mkuniversity.org
}

MS received 5 February 2018; revised 16 March 2018; accepted 2 April 2018; published online 29 June 2018

\begin{abstract}
The fixation of carbon dioxide $\left(\mathrm{CO}_{2}\right)$ is an important global challenge. A significant increase of the atmospheric $\mathrm{CO}_{2}$ due to the industrial emissions and a steady increase in combustion of fossil fuels is a widespread environmental concern. This article is a short literature review on the recent developments in the field of $\mathrm{CO}_{2}$ activation and fixation by bioinspired copper(II) catalysts. In our laboratory, copper(II) complexes of bidentate ligands have been reported as catalysts for the fixation of $\mathrm{CO}_{2}$. The molecular structure of one of the complexes has shown unusual trigonal bipyramid geometry $(\tau, 0.936)$ by the coordination of two ligand units and a water molecule. All the complexes exhibited a well-defined $\mathrm{Cu}(\mathrm{II}) / \mathrm{Cu}(\mathrm{I})$ redox potentials around 0.352 to $0.401 \mathrm{~V}$ in acetonitrile. The rhombic EPR spectra of the complexes indicate the existence of a geometrical equilibrium between trigonal bipyramidal and square pyramidal at $70 \mathrm{~K}$. The $\mathrm{d}-\mathrm{d}$ transitions around 750 800 and 930-955 nm further supports five coordination geometry in solution. These copper(II) complexes have successfully fixed atmospheric $\mathrm{CO}_{2}$ as $\mathrm{CO}_{3}^{2-}$ by using $\mathrm{Et}_{3} \mathrm{~N}$ as sacrificial reducing agent and afforded $\left[\mathrm{Cu}(\mathrm{L}) \mathrm{CO}_{3}\left(\mathrm{H}_{2} \mathrm{O}\right)\right]$. The $\mathrm{CO}_{3}^{2-}$ bound complex has shown a distorted square pyramidal geometry $(\tau, 0.369)$ around copper(II) center via the coordination of only one ligand unit, a carbonate, and water molecules. The catalysts are active enough to fix $\mathrm{CO}_{2}$ for eight repeating cycles without any change in the efficiency. The fixation of $\mathrm{CO}_{2}$ possibly proceeds via the formation of $\mathrm{Cu}(\mathrm{I})$-species. This is supported by $\mathrm{X}$-ray structure, which reveals distorted tetrahedral geometry by the coordination of two units of ligand.
\end{abstract}

Keywords. Carbon dioxide fixation; sequestration; copper(II)complexes; catalysis - reaction mechanism.

\section{Introduction}

Carbon dioxide $\left(\mathrm{CO}_{2}\right)$ is one of the main greenhouse gases causing global warming and climate change. The atmospheric $\mathrm{CO}_{2}$ concentration is steadily increasing due to industrial emissions and prodigious usage of fossil fuels. ${ }^{1-3}$ These result in the continuous rise of the global average temperature. In recent years, capture of $\mathrm{CO}_{2}$ and carbon recycling have gained great attention as they could help in carbon recycling, thereby mimicking Nature that makes thousands of compounds from atmospheric $\mathrm{CO}_{2} \cdot{ }^{4,5}$ Alternatively, great efforts are made to develop techniques for carbon capture and storage (CCS) to fix atmospheric $\mathrm{CO}_{2}$ and store in a supercritical

\footnotetext{
*For correspondence
}

state. ${ }^{6}$ Another rational approach is to utilize $\mathrm{CO}_{2}$ as $\mathrm{C} 1$ building block for synthesizing valuable organic compounds due to the low cost and nontoxicity of $\mathrm{CO}_{2} \cdot{ }^{1-3,7-9}$ However, the utilization of carbon dioxide is challenging, as it is a non-polar linear molecule containing carbon in higher oxidation state. It is thermodynamically stable with a short $\mathrm{C}=\mathrm{O}$ bond distance $1.16 \AA \mathrm{A}^{10}$ So far, four major methods such as chemical, $, 1,3,7-9$ photochemical, ${ }^{11}$ electrochemical ${ }^{11-13}$ and enzymatic methods ${ }^{7-9,14}$ are exploited to catalyze the $\mathrm{CO}_{2}$ fixation/ conversion. In the first three methods, the low selectivity is often reported due to the stable form of the carbon in the $\mathrm{CO}_{2}$ molecule and it is energetically challenging to acquire high catalytic performances. ${ }^{1,3,7-14}$ The enzymatic method provides an eco-friendly and promising way for efficient $\mathrm{CO}_{2}$ fixation/conversion through superior stereo-specificity and regio/chemoselectivity. ${ }^{13,15-18}$ The metalloenzyme carbon monoxide 

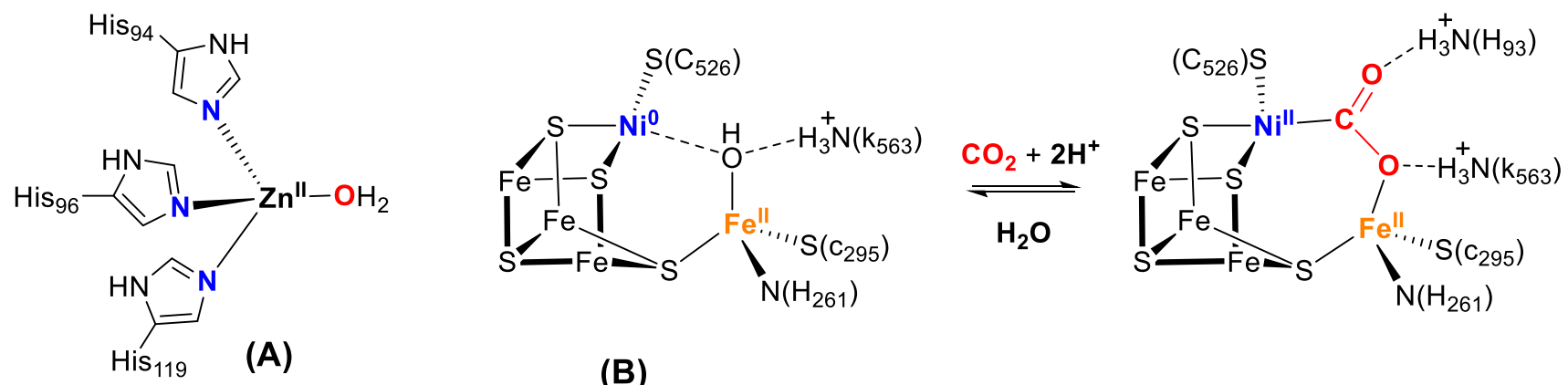

(B)

Scheme 1. The active site of carbonic anhydrase enzyme (A) and carbon monoxide dehydrogenase (B).

dehydrogenase $(\mathrm{CODH})$ is capable of performing both $\mathrm{CO}_{2}$ to $\mathrm{CO}$ reduction and $\mathrm{CO}$ to $\mathrm{CO}_{2}$ oxidation. The $[\mathrm{Ni}-4 \mathrm{Fe}-4 \mathrm{~S}]$ core adopted by $\mathrm{CODH}$ active site to handle this redox-mediated interconversion. ${ }^{19}$ The zinc(II) containing carbonic anhydrase enzyme catalyzes $\mathrm{CO}_{2}$ to $\mathrm{CO}_{3}^{2-}$ conversion via non-redox pathway at $\mathrm{pH}$ of 7.0 and D-ribulose-1,5-bisphosphate carboxylase/oxygenase in the photosystem II is known to play crucial roles in the fixation and activation of $\mathrm{CO}_{2}$ (Scheme 1). ${ }^{20-27}$

The current state of the work in this field has been well summarized in a few reviews giving wider perspective. ${ }^{28-32}$ Kitajima and co-workers reported the hydroxo complexes of a divalent metal ( $\mathrm{Mn}, \mathrm{Fe}, \mathrm{Co}$, $\mathrm{Ni}, \mathrm{Cu}$, and $\mathrm{Zn}$ ) using hindered tris(pyrazoly1)borate ligand (hydrotris(3,5-diisopropyl-1-pyrazolyl)-borate). The reactivities of the hydroxo complexes towards $\mathrm{CO}_{2}$ fixation are reported in the order of $\mathrm{Zn}^{2+}>$ $\mathrm{Cu}^{2+}>\mathrm{Ni}^{2+}=\mathrm{Co}^{2+}>\mathrm{Mn}^{2+}>\mathrm{Fe}^{2+} \cdot{ }^{33} \mathrm{But}$ only a few attempts have been made for $\mathrm{CO}_{2}$ activation and fixation using ecologically viable copper catalysts. In the present review, we briefly discussed the salient features of previous reports and our very recent findings ${ }^{34}$ in $\mathrm{CO}_{2}$ fixation by using copper catalysts. In our work, we have isolated mononuclear copper(II) complexes of simple bidentate ligands. The steric and electronic influence of the ligand nitrogen donor set on the spectral and redox behavior and $\mathrm{CO}_{2}$ fixation reactions have been probed. The X-ray crystal structures of one of the complexes, a key $\mathrm{Cu}(\mathrm{I})$ intermediate, and product-bound complexes have been determined. ${ }^{34}$

\section{Fixation of $\mathrm{CO}_{2}$ to $\mathrm{CO}_{3}^{2-}$}

In 2004, Garcia-Espanaa and co-workers showed the fixation of $\mathrm{CO}_{2}$ into carbonate by using copper(II) complexes of a terpyridinophane aza receptor at $\mathrm{pH}, 9-10 .{ }^{35}$ The in situ generated mononuclear copper(II) complex afforded carbamate-bound complexes. On the other hand, in situ generated dinuclear complex catalyzed the formation of carbonate-bound complexes (Scheme 2). ${ }^{35}$ The carbamate and bicarbonate are coordinated to copper center as bridging ligands within the hydrophobic macrocyclic cavity. However, the copper(II) complexes of ligands containing the same polyamine bridge but pyridine or phenanthroline spacers fail to show fixation of $\mathrm{CO}_{2}$ under identical conditions.

Comba and coworkers have reported the dicopper(II) complexes of pseudo-octapeptides, synthetic analogs of ascidiacyclamide and the patellamide ligands as the copper-containing carbonic anhydrase models. ${ }^{36}$ The ascidiacyclamide and the patellamides are found in ascidians of the Pacific and Indian Oceans. These complexes are projected as an efficient model for carbonic anhydrase with $k_{\text {cat }}$ up to $7.3 \times 10^{3} \mathrm{~s}^{-1}$ and a turnover number (TON) of at least 1700, which is closer to the enzyme-catalyzed reaction $\left(k_{c a t}, 2 \times 10^{5}\right.$ $1.4 \times 10^{6} \mathrm{~s}^{-1}$ ). The $k_{\text {cat }}$ depends on the configuration of the isopropyl side chains of the pseudo-octapeptide scaffold, and the naturally observed $\mathrm{R}^{*}, \mathrm{~S}^{*}, \mathrm{R}^{*}, \mathrm{~S}^{*}$ geometry is revealed as more efficient than the $S^{*}, S^{*}, S^{*}, S^{*}$ catalyst isomers. The heterocyclic donor groups of the pseudo-octapeptides vary the catalytic efficiency of the complexes. The dicopper(II) complex of the ligand with four imidazole groups is a more efficient catalyst than that of the close analog of ascidiacyclamide with two thiazole and two oxazoline rings. The conversion of $\mathrm{CO}_{2}$ into $\mathrm{CO}_{3}^{2-}$ proceeded via nucleophilic attack of a $\mathrm{Cu}$ (II)-coordinated hydroxide as similar to $\mathrm{Zn}(\mathrm{II})$ containing carbonic anhydrase enzymes. They observed that the formation of the catalyst- $\mathrm{CO}_{2}$ adduct and release of carbonate/bicarbonate are relatively fast processes (Scheme 3). ${ }^{36}$

Mautner and co-workers have synthesized two carbanatobridged copper(II) complexes $\left[\mathrm{Cu}_{3}(\mathrm{dmMePEA})_{3}\left(\mu_{3}-\mathrm{CO}_{3}\right)\right.$ $\left.\left(\mathrm{ClO}_{4}\right)_{3}\right] \mathrm{ClO}_{4}$ and $\mathrm{Cu}_{2}$ (iptren $\left.)_{2}\left(\mu_{3}-\mathrm{CO}_{3}\right)\right]\left(\mathrm{ClO}_{4}\right)_{2} \cdot \mathrm{H}_{2} \mathrm{O}$ from $\mathrm{Cu}\left(\mathrm{ClO}_{4}\right)_{2}$ and a polydentate amine ligand, dmMePEA $=\mathrm{N}-$ ((4-methoxy-3,5-dimethylpyridin-2-yl)methyl)-N-methyl-2(pyridin-2-yl)ethan-1-amine and iptren $=\mathrm{N}^{\prime}$-isopropyl- $\mathrm{N}^{\prime \prime}$, $\mathrm{N}^{\prime \prime}$-bis(2-(isopropylamino)ethyl)-ethane-1,2-diamine. The $\mathrm{CO}_{3}^{2-}$ is formed from the atmospheric $\mathrm{CO}_{2}$ under slightly basic methanol solution. The various coordination modes of $\mathrm{CO}_{3}^{2-}$ ion and magnetic properties were reported. ${ }^{37}$ However, these reports fail to explain the mechanism of $\mathrm{CO}_{2}$ fixation and employed alkaline $\mathrm{pH}$. 


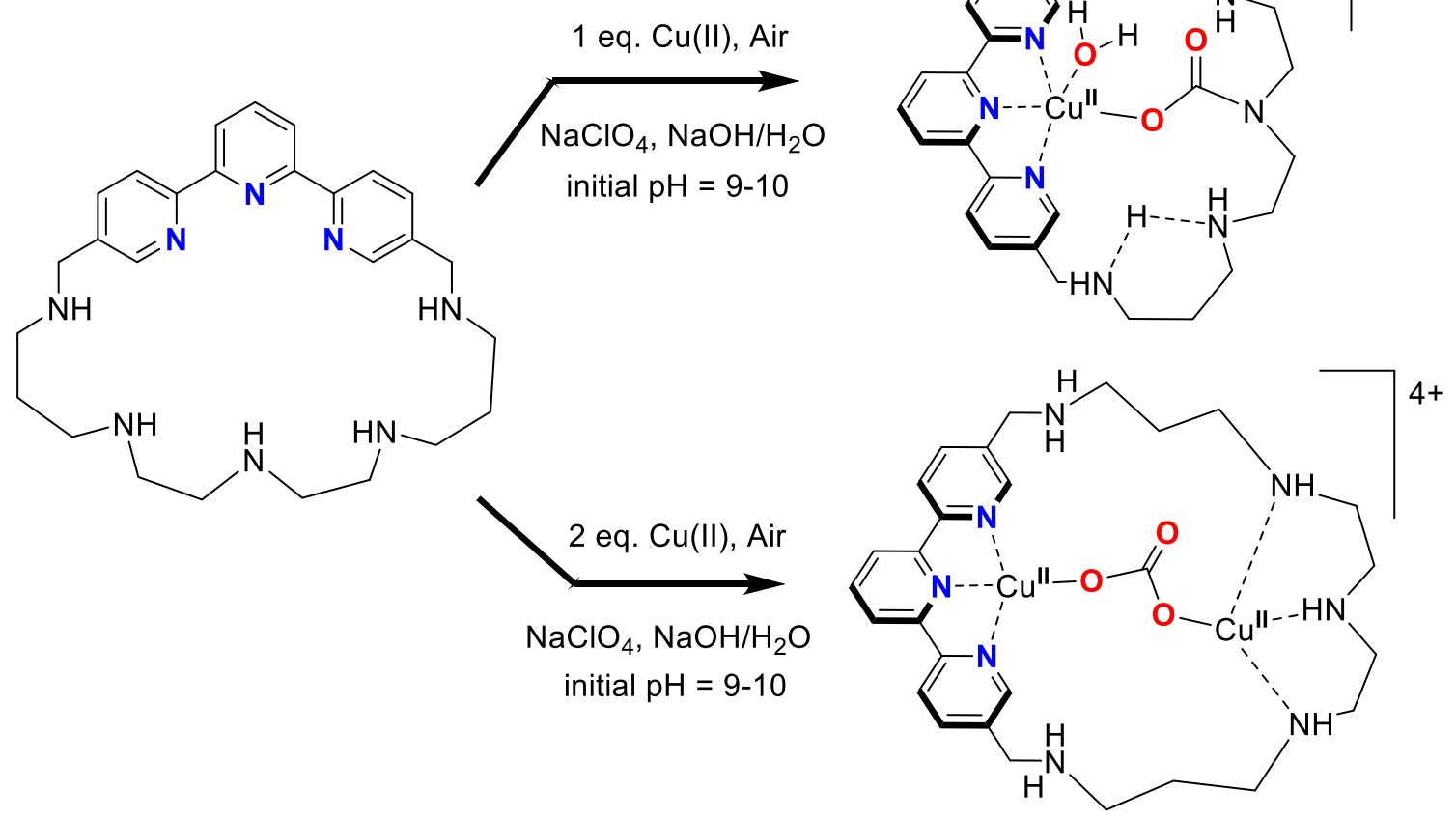

Scheme 2. Fixation of $\mathrm{CO}_{2}$ as carbomate and carbonate.

\section{Fixation of $\mathrm{CO}_{2}$ to $\mathrm{C}_{2} \mathrm{O}_{4}^{2-}$}

In 2001, Peacock and co-workers reported the first example of $\mathrm{CO}_{2}$ reduction into oxalate catalyzed by copper(II) complex of $N, N^{\prime}, N^{\prime \prime}$-triallyl-1,4,7-triazacyclononane and isolated $\left[\mathrm{LCu}\left(\mu-\mathrm{C}_{2} \mathrm{O}_{4}\right) \mathrm{CuL}\right]\left[\mathrm{Ph}_{4} \mathrm{~B}\right]_{2}$ as a byproduct while synthesizing $[\mathrm{LCu}(\mu-\mathrm{OH}) \mathrm{CuL}]$ $\left(\mathrm{BPh}_{4}\right)_{2}$ by aerial oxidation. ${ }^{38}$ The structure of $[\mathrm{LCu}(\mu-$ $\left.\left.\mathrm{C}_{2} \mathrm{O}_{4}\right) \mathrm{CuL}\right]\left[\mathrm{Ph}_{4} \mathrm{~B}\right]_{2}$ and its formation are further established using $\mathrm{CsHCO}_{3}$. The oxalate formation is proposed to proceeds via the intermediate $\left[\mathrm{LCu}^{I I}\left(\mathrm{HCO}_{3}^{\bullet-}\right]^{+}\right.$ triggered by internal electron transfer (Scheme 4). Later in 2010, Bouwman and co-workers have impressively shown the electrocatalytic conversion of $\mathrm{CO}_{2}$ into oxalate. It is catalyzed by a pre-organized dinuclear copper complex of disulfide ligand of [N-(2-mercaptopropyl)- $N, N$-bis(2-pyridylmethyl)amine. ${ }^{39}$

The reduction of the binuclear $\mathrm{Cu}$ (II) complex and subsequent activation of $\mathrm{CO}_{2}$ resulted in the formation of bis(oxalate)-bound tetranuclear $\mathrm{Cu}$ (II) complex. The oxalate ligands are coordinated to copper(II) centers via head-to-head bridging. The coordinated oxalate is electrocatalytically released as insoluble $\mathrm{Li}_{2} \mathrm{C}_{2} \mathrm{O}_{4}$ by the reaction of supporting electrolyte used $\left(\mathrm{LiClO}_{4}\right)$ and regenerated the original copper(II) complexes in acetonitrile (Scheme 5). The catalytic turnover has been achieved by applying the potential of $-0.03 \mathrm{~V}$ vs NHE which facilitates the reduction of $\mathrm{Cu}$ (II) to
$\mathrm{Cu}(\mathrm{I})$ followed by $\mathrm{CO}_{2}$ fixation. This potential is almost $2 \mathrm{~V}$ less negative than that required for the outersphere reduction of $\mathrm{CO}_{2}$ to $\mathrm{CO}$ but closer to that for oxalate $(0.39 \mathrm{~V})$. The $\mathrm{Cu}(\mathrm{I})$ complex is selectively oxidized by $\mathrm{CO}_{2}$ rather than $\mathrm{O}_{2}$ as it offers a lowenergy pathway to the formation of the metal bound $\mathrm{CO}_{2}$ radical anion and then dimerized to generate the thermodynamically-favored oxalate bound complex. Maverick and co-workers reported macrocyclic complexes $\left[\mathrm{Cu}_{2}(m-\mathrm{xpt})_{2} \mathrm{X}_{2}\right]\left(\mathrm{PF}_{6}\right)_{2}\left(\mathrm{X}=\mathrm{Cl}^{-}, \mathrm{NO}_{3}^{-}\right)$that facilitated a $\mathrm{CO}_{2}$ reduction in presence of sodium ascorbate in dimethylformamide (DMF). ${ }^{40}$ The $m$-xylene spacer is used to connect two pyridyltriazole chelating units of ligand. A single complex molecule has used for reductive coupling of $\mathrm{CO}_{2}$ instead of two molecules of binuclear $\mathrm{Cu}(\mathrm{I})$ complex used in Bouwman's studies. The binuclear complex $\left[\mathrm{Cu}_{2}(m-\mathrm{xpt})_{2} \mathrm{X}_{2}\right]\left(\mathrm{PF}_{6}\right)_{2}$ selectively captures $\mathrm{CO}_{2}$ from the air and reduces it to generate oxalate and coordinated as an oxalate-bridge (Scheme 6A). ${ }^{40}$

The oxalic acid is released by treating with dilute mineral acid, which regenerates the original copper complex. Fujisawa and co-workers have reported the conversion of $\mathrm{CO}_{2}$ into oxalate by using copper(II) complexes of hydrotris(3,5-diisopropyl-1-pyrazolyl)borate anion and non-innocent ligand $\alpha$-keto acid. ${ }^{41}$ The $\alpha$-ketocarboxylato copper(II) complex $\left[\{\mathrm{Cu}(\mathrm{L})\}\left\{\mathrm{O}_{2}\right.\right.$ $\left.\left.\mathrm{CC}(\mathrm{O}) \mathrm{CH}\left(\mathrm{CH}_{3}\right)_{2}\right\}\right]$ is spontaneously converted into the 


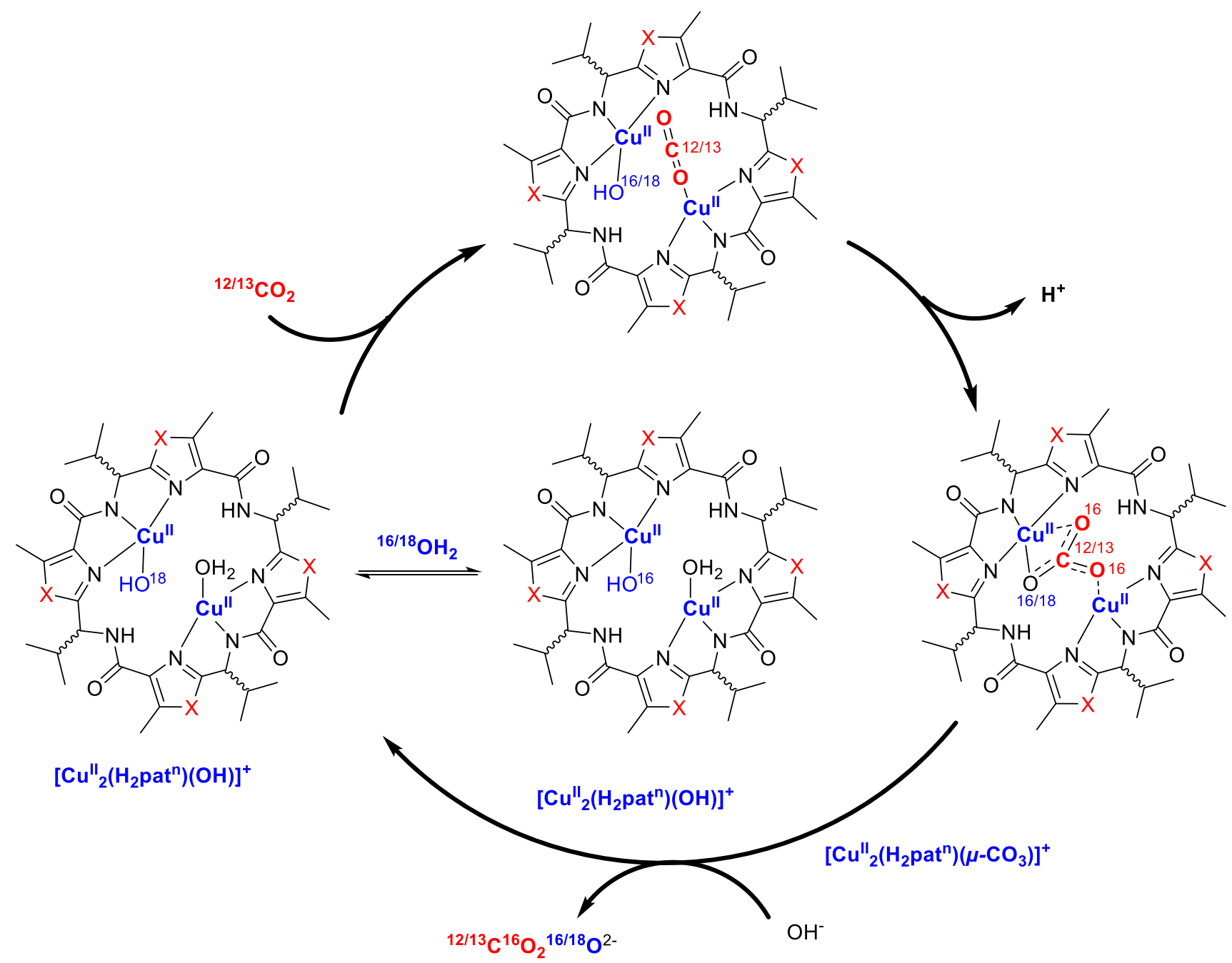

Scheme 3. $\mathrm{CO}_{2}$ fixation by the copper(II) complexes of patellamides ligands.

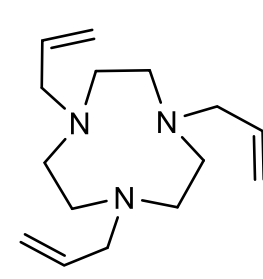

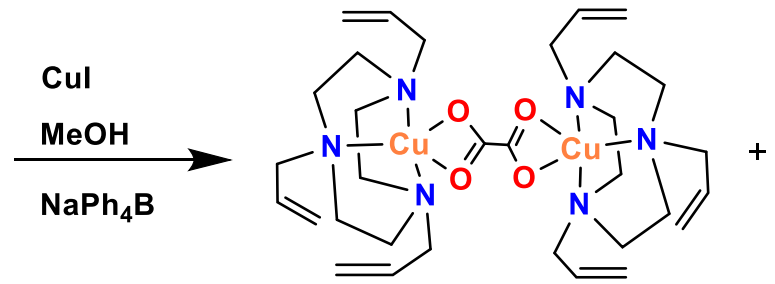

(A)

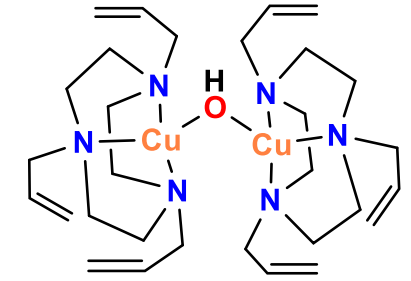

(B)

Scheme 4. The fixation $\mathrm{CO}_{2}$ as oxalate bridged copper(II) complex $\left[\mathrm{LCu}\left(\mu-\mathrm{C}_{2} \mathrm{O}_{4}\right) \mathrm{CuL}\right]\left[\mathrm{Ph}_{4} \mathrm{~B}\right]_{2}(\mathrm{~A})$ and $[\mathrm{LCu}(\mu-\mathrm{OH}) \mathrm{CuL}]\left(\mathrm{BPh}_{4}\right)_{2}(\mathrm{~B})$.

binuclear oxalato copper(II) complex $\left[\{\mathrm{Cu}(\mathrm{L})\}_{2}(\mu\right.$ $\left.\mathrm{C}_{2} \mathrm{O}_{4}\right)$ ] upon exposure to $\mathrm{O}_{2} / \mathrm{CO}_{2}$ gas (Scheme $\left.6 \mathrm{~B}\right){ }^{41}$ Additionally, the bicarbonato copper(I) complex and the $\alpha$-ketocarboxylato copper(I) complex of the same ligand were spontaneously converted into the oxalato complex $\left[\{\mathrm{Cu}(\mathrm{L} 1)\}_{2}\left(\mu-\mathrm{C}_{2} \mathrm{O}_{4}\right)\right]$ in Ar atmosphere and $\mathrm{O}_{2}$ atmosphere, respectively. Alkaline workup of the oxalato copper(II) complex released sodium oxalate from the copper coordination sphere. The formation of the oxalate ion is promoted by decomposition of the $\alpha$-ketocarboxylate ligands presumably to a $\mathrm{CO}_{2}^{\bullet-}$ radical anion that remained bound for coupling and via a side-on-coordinated oxalate ion. The conversion of copper(I) bicarbonate complex into oxalate is similar to that of Peacock's report.

\section{Copper(II) complexes of bidentate ligands}

We have an ongoing interest to develop copper complexes for $\mathrm{CO}_{2}$ fixation and study its mechanism. 

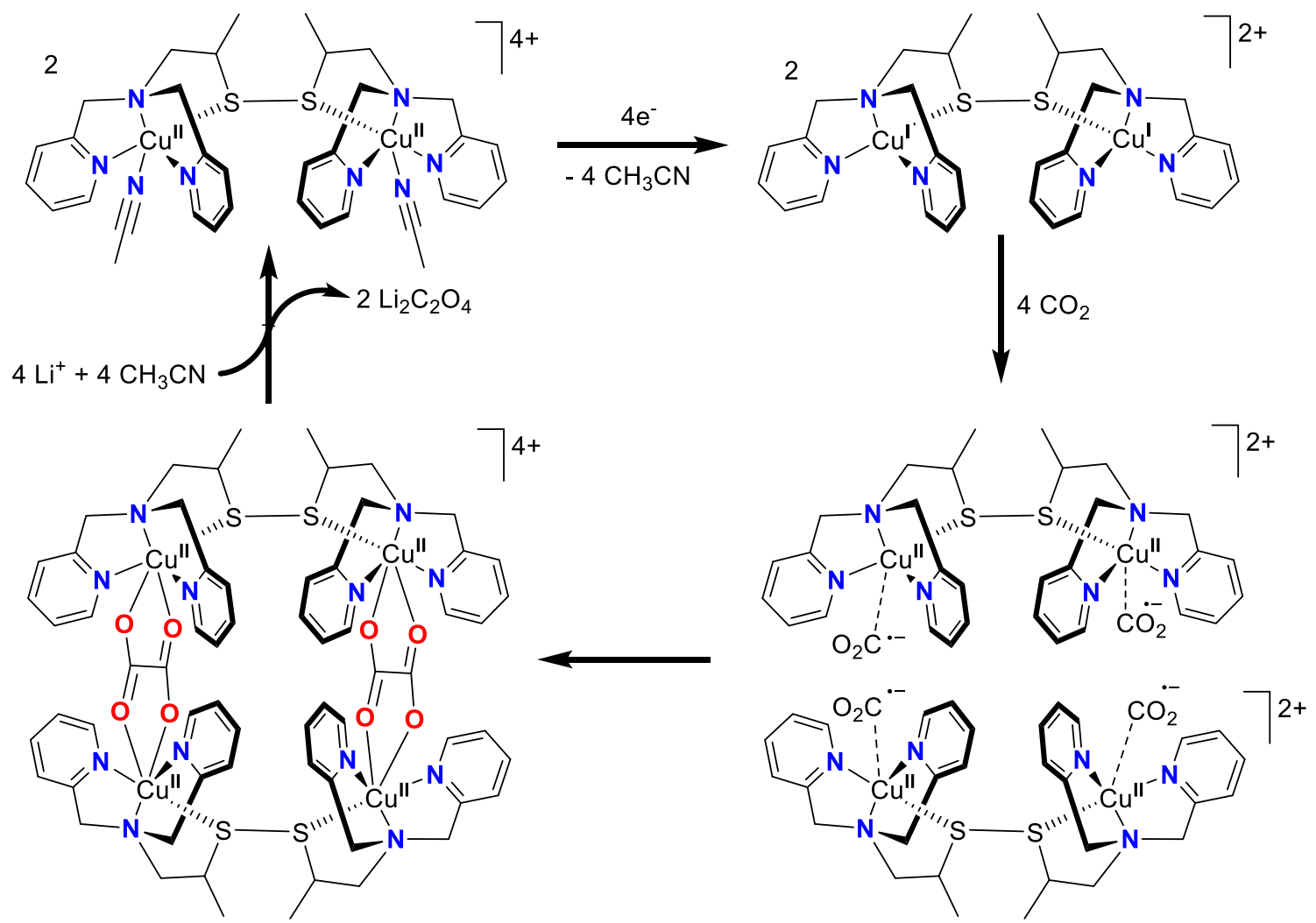

Scheme 5. Electrocatalytic reduction of $\mathrm{CO}_{2}$ into oxalate by $\mathrm{Cu}(\mathrm{I})$ complex.

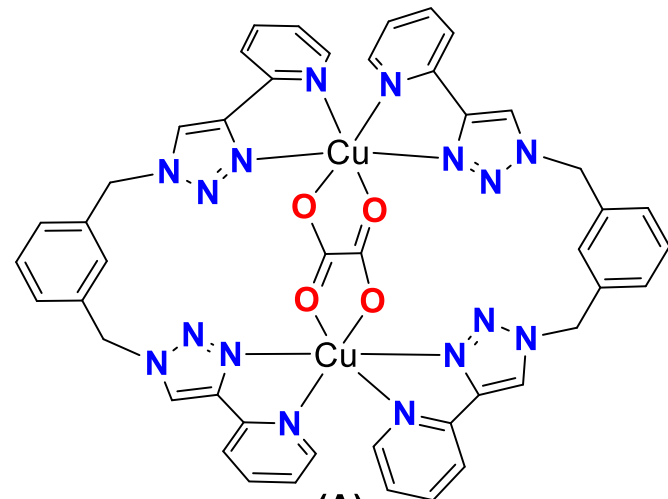

(A)

Scheme 6. Structure of oxalato copper(II) hydrotris(3,5-diisopropyl-1-pyrazolyl)borate (B).

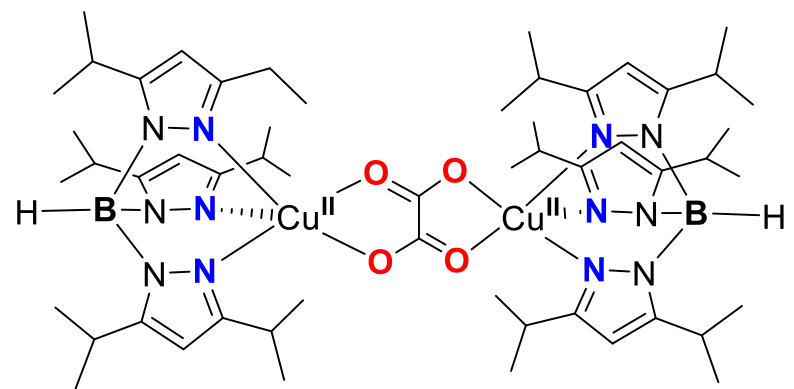

(B)
Recently, we have reported simple copper(II) complexes $\left[\mathrm{Cu}(\mathrm{L})_{2}\left(\mathrm{H}_{2} \mathrm{O}\right)\right]\left(\mathrm{ClO}_{4}\right)_{2}, \mathbf{1 - 5}$ (Scheme 7) of bidentate ligands (L1-L2). They were used as the catalyst for fixation of atmospheric $\mathrm{CO}_{2}$ under mild conditions (Scheme 7). ${ }^{34}$ The molecular structure of one of the complexes, complex bridged with $\mathrm{CO}_{3}^{2-}$ (originated from atmospheric $\mathrm{CO}_{2}$ ) and key copper(I)-intermediate have been successfully characterized by single crystal X-ray study (Figure 1). The structure of $\mathbf{2}$ exhibits a trigonal bipyramid coordination geometry around copper(II) center, which is coordinated to nitrogens of two ligand units and one equatorially coordinated water molecule. The $\mathrm{d}-\mathrm{d}$ bands around $750-800 \mathrm{~nm}$ $\left(\mathrm{d}_{x z} \approx \mathrm{d}_{y z} \rightarrow \mathrm{d}_{z}^{2}\right)$ and 930-955 nm $\left(\mathrm{d}_{x y} \approx \mathrm{d}_{x}{ }^{2}-{ }^{2} \rightarrow\right.$ $\mathrm{d}_{z}^{2}$ ) confirm the existence of five-coordinate geometry in acetonitrile solution, similar to solid state. The rhombic EPR splitting of g-values in $\mathrm{x}, \mathrm{y}$ and $\mathrm{z}$-axis indicate that the geometry is in between the trigonal bipyramidal and square pyramidal geometries with the ground state raised from a linear combination of $\mathrm{d}_{x}{ }^{2}-y{ }^{2}$ and $\mathrm{d}_{z}^{2}$ orbitals. All the complexes exhibited a welldefined $\mathrm{Cu}(\mathrm{II}) / \mathrm{Cu}(\mathrm{I})$ redox potentials around 0.352 to 

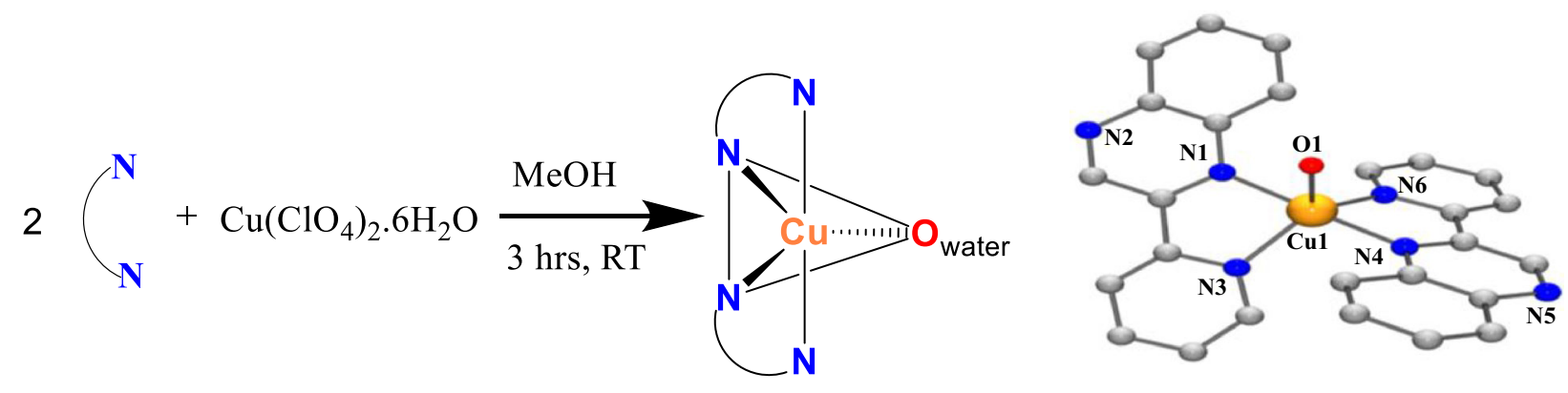

$\left[\mathrm{Cu}(\mathrm{L})_{2}\left(\mathrm{H}_{2} \mathrm{O}\right)\right]\left(\mathrm{ClO}_{4}\right)_{2} ; 1$ - 5

$\overbrace{\mathbf{N}}^{\mathbf{N}}=$<smiles>c1ccc(-c2ccc3ccccc3n2)nc1</smiles>

L1

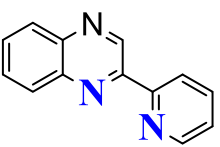

L2

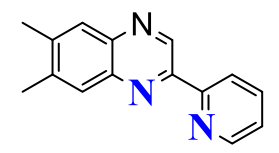

L3
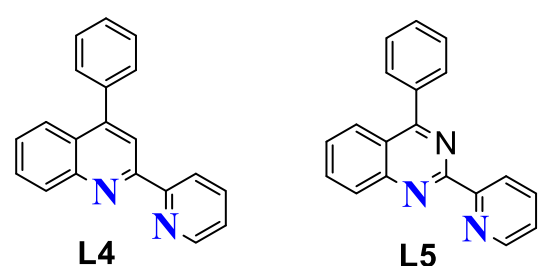

Scheme 7. Synthesis of $\mathrm{Cu}(\mathrm{II})$ complexes of bidentate ligands and the molecular structure of $\left[\mathrm{Cu}(\mathrm{L} 2)_{2}\left(\mathrm{H}_{2} \mathrm{O}\right)\right](\mathrm{ClO})_{2} 2$.
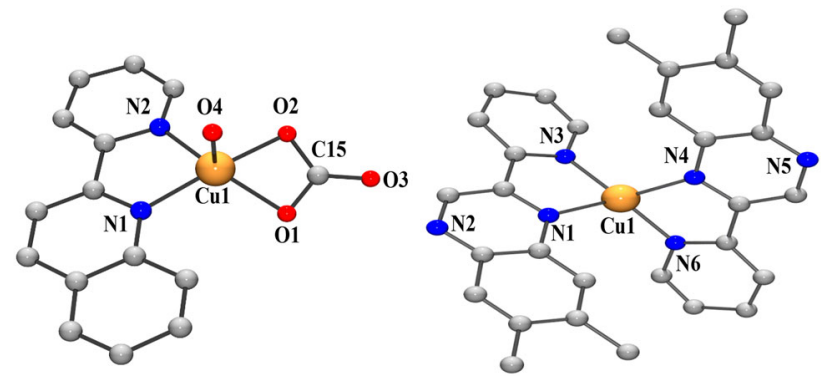

Figure 1. The molecular

structures of $\left[\mathrm{Cu}(\mathrm{L} 1)\left(\mathrm{CO}_{3}\right)\left(\mathrm{H}_{2} \mathrm{O}\right)\right] \mathbf{1 a}$ and $\mathrm{Cu}(\mathrm{I})$-species $\left[\mathrm{Cu}(\mathrm{L} 3)_{2}\right] \mathrm{ClO}_{4}$ 3 b.

$0.401 \mathrm{~V} \mathrm{Vs} \mathrm{Ag} / \mathrm{Ag}^{+}$. The fixation and kinetic studies have shown that atmospheric $\mathrm{CO}_{2}$ fixation is simultaneous and selective over other atmospheric gases. Our ligand architecture, donor properties of the heterocyclic nitrogen donors provide important differences to other related previously reported catalysts. Further, our ligands are able to adopt preferable tetrahedral coordination geometry for key copper(I) intermediate to fix carbon dioxide (cf. below). To the best of our knowledge, our report is the novel example of copper(II) complexes based on bidentate ligands for simultaneous fixation and sequestration of atmospheric carbon dioxide under mild conditions.

\subsection{Carbon dioxide fixation and kinetic studies}

The $\mathrm{CO}_{2}$ fixation reaction was catalyzed by $\mathbf{1 - 5}$ in acetonitrile at room temperature and $\mathrm{Et}_{3} \mathrm{~N}$ used as sacrificial reducing agent. ${ }^{42,43}$ The complex $\mathbf{1}$ catalyzed fixation of atmospheric $\mathrm{CO}_{2}$ and afforded a complex of blue color, $\left[\mathrm{Cu}(\mathrm{L} 1)\left(\mathrm{CO}_{3}\right)\left(\mathrm{H}_{2} \mathrm{O}\right)\right]$ (1a) with a yield of $29 \%$ in presence of one equivalent $\mathrm{Et}_{3} \mathrm{~N}$. The efficiency of $\mathrm{CO}_{2}$ fixation was enhanced and shown a yield of $74 \%$ while purging pure $\mathrm{CO}_{2}$ gas under the identical conditions. 1a has shown a new electronic absorption band at $614 \mathrm{~nm}\left(\varepsilon, 362 \mathrm{M}^{-1} \mathrm{~cm}^{-1}\right)$ and IR stretching frequency at $1647 \mathrm{~cm}^{-1}$ for bound $\mathrm{CO}_{3}^{2-}$. This $\mathrm{CO}_{3}^{2-}$ bound complex was successfully crystallized from the reaction mixture and its molecular structure shows distorted square pyramidal geometry $(\tau, 0.369)$ around copper(II) center via the coordination of only one ligand unit, a carbonate, and water molecules. One of the ligand units in the parent complex is replaced by more basic $\mathrm{CO}_{3}^{2-}$ ion $\left(\mathrm{pK}_{a}, 10.2\right)$, which is originated from $\mathrm{CO}_{2}$. The addition of one equivalent of $\mathrm{H}^{+}(\mathrm{HCl})$ to $1 \mathrm{a}$ liberates $\mathrm{HCO}_{3}^{-}$and regenerates $\mathbf{1}$. This regeneration of $\mathbf{1}$ is well supported by the appearance of mass values $m / z, 475.08$ in ESI-MS and d-d transition band around 776 and $943 \mathrm{~nm}$ is similar to the spectral signatures of $\mathbf{1}$. Further, $1 \mathrm{a}$ exhibited less positive $\mathrm{Cu}(\mathrm{II}) / \mathrm{Cu}(\mathrm{I})$ redox potential $(0.090 \mathrm{~V})$ than that of $1(0.390 \mathrm{~V})$. This is possibly due to the coordination of better electron donor $\mathrm{CO}_{3}^{2-}$ anion, which increases the electron density around copper center as compared to the ligand L1. Similarly, the fixation of atmospheric $\mathrm{CO}_{2}$ by using 2 with $\mathrm{Et}_{3} \mathrm{~N}$ yielded a blue color solid $\left[\mathrm{Cu}(\mathrm{L} 2)\left(\mathrm{CO}_{3}\right)\left(\mathrm{H}_{2} \mathrm{O}\right)\right](\mathbf{2 a})$ and the yield is almost identical $(26 \%)$ to $1 \mathrm{a}$ and increased to $73 \%$ on purging pure $\mathrm{CO}_{2}$ gas under identical condition. The complex 3 afforded the highest amount of $\mathrm{CO}_{2}$ fixation and yielded 


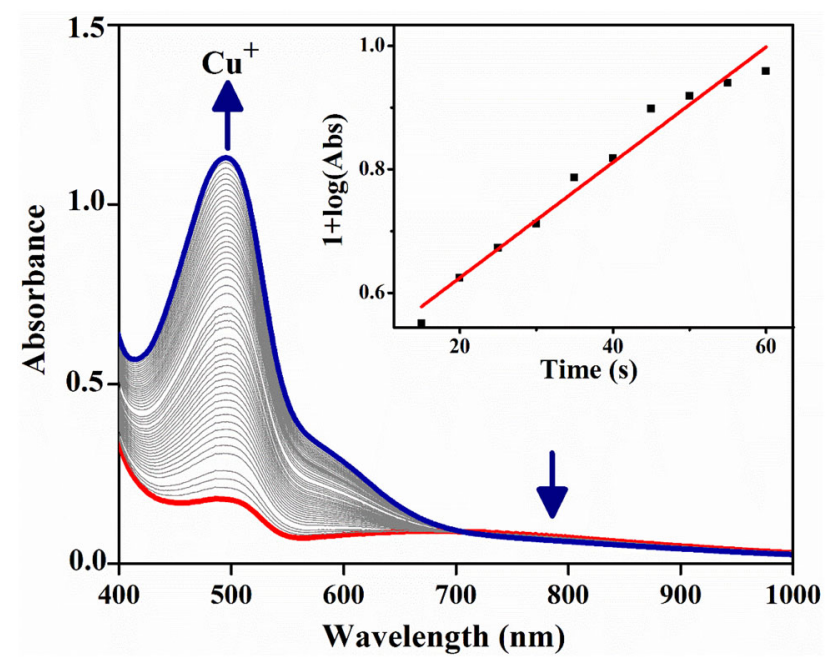

Figure 2. The kinetics of $\mathrm{Cu}(\mathrm{I})$-species formation by the reaction of $1\left(1 \times 10^{-3} \mathrm{M}\right)$ with one equivalent of $\mathrm{Et}_{3} \mathrm{~N}$ in acetonitrile at $25^{\circ} \mathrm{C}$. Inset: plot of $[1+\log (\mathrm{abs})]$ vs time.

$\left[\mathrm{Cu}(\mathrm{L} 3)\left(\mathrm{CO}_{3}\right)\left(\mathrm{H}_{2} \mathrm{O}\right)\right]$ (3a) of $32 \%$ and $81 \%$ using atmosphere and pure $\mathrm{CO}_{2}$, respectively. The complex $\mathbf{3}$ with electron donating methyl group offers more nucleophilic nature on the metal center and facilitates efficient $\mathrm{CO}_{2}$ fixation. On the other hand, the phenyl substituted complexes $\mathbf{4}$ and $\mathbf{5}$ exhibited only decreased amounts of $\mathrm{CO}_{3}^{2-}$ bound complexes $\left[\mathrm{Cu}(\mathrm{L} 4)\left(\mathrm{CO}_{3}\right)\left(\mathrm{H}_{2} \mathrm{O}\right)\right](\mathbf{4 a})$ and $\left[\mathrm{Cu}(\mathrm{L} 5)\left(\mathrm{CO}_{3}\right)\left(\mathrm{H}_{2} \mathrm{O}\right)\right](\mathbf{5 a})$, respectively, from the atmosphere $(\sim 20 \%)$ and pure $\mathrm{CO}_{2}(\sim 66 \%)$ under identical conditions. The lower yield of $\mathbf{4 a}$ and $\mathbf{5 a}$ is possibly due to electron withdrawing nature of phenyl groups and that invariably decrease the nucleophilicity on metal center leads to less $\mathrm{CO}_{2}$ fixation. Similar to $1 \mathbf{a}$, the $\mathrm{Cu}$ (II)/Cu(I) redox potential of $\mathbf{2 a}-\mathbf{5} \mathbf{a}$ are less positive than those of their respective parent complexes. The IR stretching frequency for copper-bound $\mathrm{CO}_{3}^{2-}$ appeared almost in the same region at $1649 \mathrm{~cm}^{-1}$ for 3a-5a, identical to $\mathbf{1 a}$.

The $\mathrm{CO}_{2}$ fixation mechanism is possibly operating via copper(I) species followed by deprotonation of the coordinated water molecule. Then, $\mathrm{CO}_{2}$ is activated through the nucleophilic attack as similar to the carbonic anhydrase enzyme. ${ }^{21-24}$ The formation of copper(I) species is spectroscopically monitored by the absorption band around $450-500 \mathrm{~nm}$. The complex 1 shows formation of copper(I) species with the rate $\left(k_{\text {obs }}\right)$ of $9.35 \times 10^{-3}$ $\mathrm{s}^{-1}$ (Figure 2) and this rate for $\mathbf{1}$ is almost identical to that of $2\left(8.72 \times 10^{-3} \mathrm{~s}^{-1}\right)$ and $\mathbf{3}\left(10.31 \times 10^{-3} \mathrm{~s}^{-1}\right)$. A slight decrease in the rate of formation is observed for $4\left(5.41 \times 10^{-3} \mathrm{~s}^{-1}\right)$ and $5\left(5.57 \times 10^{-3} \mathrm{~s}^{-1}\right)$ due to steric hindrance offered by phenyl groups. Interestingly, the copper(I) species $\left[\mathrm{Cu}(\mathrm{L} 3)_{2}\right] \mathrm{ClO}_{4}(\mathbf{3 b})$ of 3 has been crystallized from the reaction mixture. It adopted a distorted tetrahedral geometry by the coordination of two units of ligand L3 (Figure 1) and a perchlorate anion in the outer coordination sphere. The reduced copper(I) species is nucleophilic in nature and subsequently reacts with $\mathrm{CO}_{2}$ molecule and then finally yielded the corresponding $\mathrm{CO}_{3}^{2-}$ bound complex of type $\left[\mathrm{Cu}(\mathrm{L})\left(\mathrm{CO}_{3}\right) \mathrm{H}_{2} \mathrm{O}\right]$.

A completely distinct $\mathrm{CO}_{3}^{2-}$ to $\mathrm{Cu}$ (II) LMCT transition around 614-673 nm was observed for $\mathrm{CO}_{3}^{2-}$ bound complexes along with the disappearance of original d$\mathrm{d}$ transitions. The treatment of $\mathrm{CO}_{3}^{2-}$ bound complexes with one equivalent of $\mathrm{H}^{+}(\mathrm{HCl})$ resulted in regeneration of the respective parent copper(II) complexes by aerial oxidation ${ }^{42,43}$ or possibly facilitated by $\mathrm{H}^{+}$. The purging of $\mathrm{CO}_{2}$ into this solution results in the formation of $\mathrm{CO}_{3}^{2-}$ bound complexes again. The catalysts were active up to eight consecutive cycles and a thereafter a slight decrease in efficiency was noted in every subsequent step. The blank reaction without catalyst showed no fixation of atmospheric or pure $\mathrm{CO}_{2}$ under identical conditions. Also, no $\mathrm{CO}_{2}$ fixation was observed while using copper(II) complexes without sacrificial reducing agent $\mathrm{Et}_{3} \mathrm{~N}$. The $\mathrm{Et}_{3} \mathrm{~N}$ facilitates the one electron reduction of $\mathrm{Cu}$ (II) into $\mathrm{Cu}(\mathrm{I})$-species ${ }^{44,45}$ and subsequently $\mathrm{CO}_{2}$ fixation. The involvement of $\mathrm{Cu}(\mathrm{I})$-species in $\mathrm{CO}_{2}$ fixation has been reported by Bouwman and co-workers ${ }^{39}$ and Maverick co-workers. ${ }^{40}$ However, interestingly, Comba and co-workers have reported the involvement of $\mathrm{Cu}$ (II)-species using patellamides ligands. ${ }^{36}$ The analogs copper(II) complexes of 2,2'-bipyridine and 1,10-phenanthroline showed no concomitant $\mathrm{CO}_{2}$ fixation from the atmosphere or pure $\mathrm{CO}_{2}$ under identical conditions. Also, well-explored copper(II) complexes $[\mathrm{Cu}(\mathrm{BPMN})]\left(\mathrm{ClO}_{4}\right)_{2}\left(\mathrm{BPMN}=N, N^{\prime}\right.$-bis $(2-$ pyridylmethyl)- $N, N^{\prime}$-dimethylethane-1,2-diamine), $[\mathrm{Cu}$ (iso-bpmen) $]\left(\mathrm{ClO}_{4}\right)_{2} \quad$ (iso-bpmen $=N, N$-bis (2-pyridylmethyl)- $N^{\prime}, N^{\prime \prime}$-dimethylethane-1,2-diamine) exhibited no fixation of $\mathrm{CO}_{2}$ under similar reaction conditions.

The $\mathrm{CO}_{2}$ fixation mechanism possibly proceeds through the geometrical conversion from trigonal bipyramidal to flattened tetrahedral geometry during the reduction of copper(II) to copper(I) and then to square pyramidal geometry at the product formation stage (Scheme 8). These processes are accomplished with the loss of the water molecule and with slight changes in $\mathrm{Cu}$ $\mathrm{N}$ bond distances and followed by the displacement of one of the ligand units by $\mathrm{CO}_{3}^{2-}$ ion. The ligand architecture, donor properties of the heterocyclic nitrogen donors and the enforced structures provide important differences to other catalysts reported. The ligands L1-L5 have the unique ability to provide a preferable tetrahedral coordination geometry for stabilization of key copper(I) intermediate and subsequent carbon dioxide fixation. The analogs copper(II) complexes 

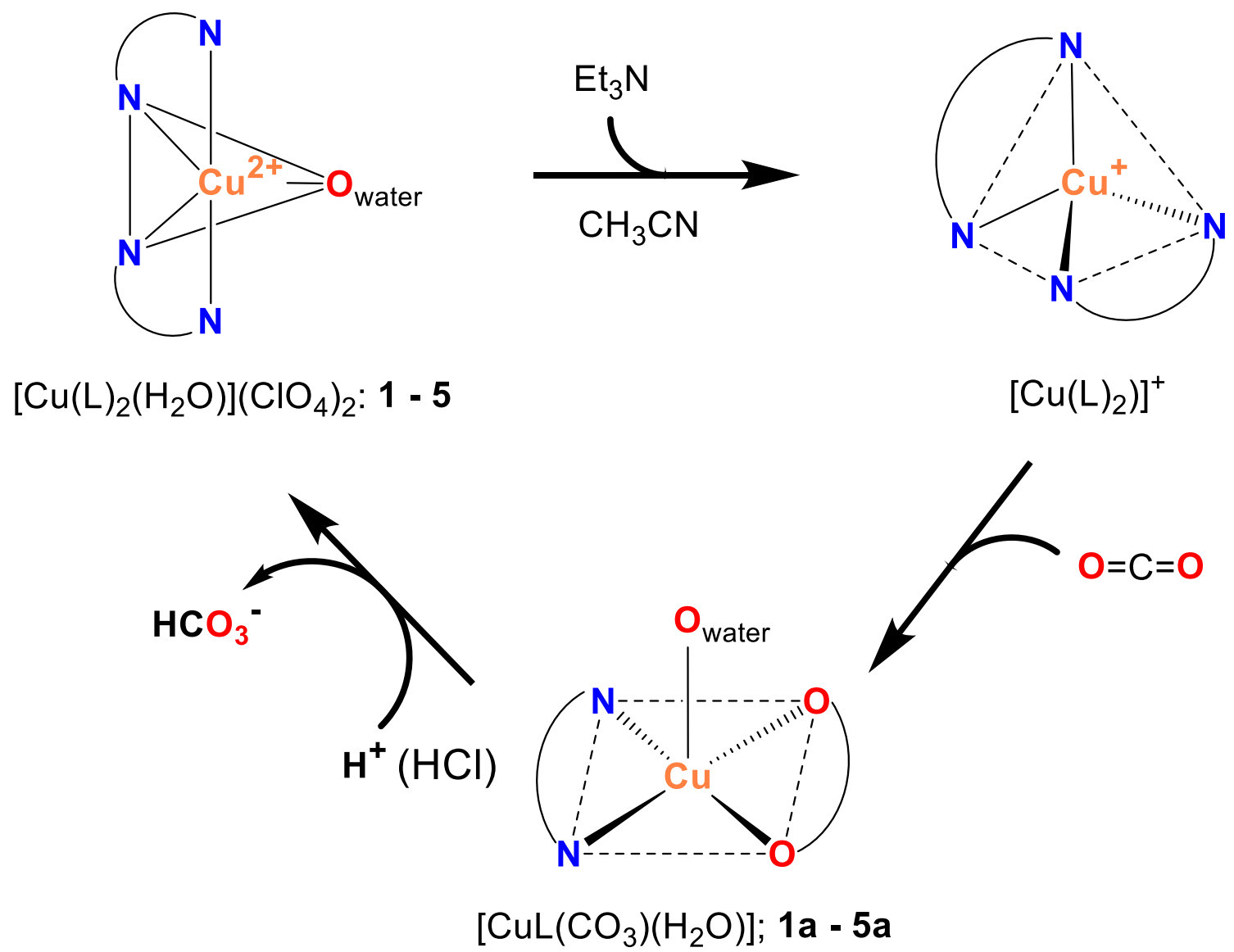

Scheme 8. Fixation of $\mathrm{CO}_{2}$ by $\mathbf{1 - 5}$ and their catalytic cycle.

of 2,2'-bipyridine, 1,10-phenanthroline and relevant linear tetradentate N4 ligands were unable to stabilize copper(I)-species for carbon dioxide fixation from the atmosphere and commercial source under identical conditions.

\section{Summary}

In summary, previously reported copper(II) complexes mostly utilized polydentate macrocyclic and tripodal ligands, which facilitated the conversion of $\mathrm{CO}_{2}$ into carbonate and oxalate via nucleophilic attack of a $\mathrm{Cu}$-coordinated hydroxide and $\mathrm{CO}_{2}^{--}$radical anion, respectively. Our copper(II) complexes used only simple bidentate ligands and they catalyzed selective fixation of $\mathrm{CO}_{2}$ from the atmosphere. The single crystal X-ray structure of one of the complexes showed an unusual trigonal bipyramid geometry around copper(II) center, coordinated to two ligand units and a water molecule. The complexes exhibited a well-defined $\mathrm{Cu}$ (II)/Cu(I) reduction potentials around 0.352 to $0.401 \mathrm{~V}$, which are more positive than $\mathrm{CO}_{2}$ reduction potential. The d-d transitions and unusual rhombic EPR spectra of the complexes reveal a geometry in between the trigonal bipyramidal and square pyramidal. Atmospheric $\mathrm{CO}_{2}$ has been fixed as $\mathrm{CO}_{3}^{2-}$ selectively using $\mathrm{Et}_{3} \mathrm{~N}$ as a sacrificial reducing agent. One of the $\mathrm{CO}_{3}^{2-}$ bound complexes shows distorted square pyramidal geometry around copper(II) center via the coordination of only one ligand unit, a carbonate and water molecules. The fixation of $\mathrm{CO}_{2}$ possibly proceeds via the copper(I) species, which is accomplished by the geometrical interconversions. One of the key copper(I) intermediate has been crystallized in distorted tetrahedral geometry by the coordination of two units of ligand. The bound carbonate was liberated as $\mathrm{HCO}_{3}^{-}$by addition of $\mathrm{H}^{+}$and regenerated the parent complexes under $\mathrm{N}_{2}$ atmosphere. The regenerated catalysts were active up to eight consecutive cycles. The catalytic and kinetic studies have shown that fixation of atmospheric $\mathrm{CO}_{2}$ by the present complexes is selective and simultaneous over other atmospheric gases under mild conditions.

\section{Acknowledgements}

We acknowledge Science and Engineering Research Board (SERB), New Delhi and Board of Research in Nuclear Science (BRNS), Mumbai for funding. 


\section{References}

1. Aresta M, Dibenedetto A and Angelini A 2014 Catalysis for the valorization of exhaust carbon: from $\mathrm{CO}_{2}$ to chemicals, materials, and fuels. Technological use of $\mathrm{CO}_{2}$ Chem. Rev. 1141709

2. Lindsey A S and Jeskey H 1957 The kolbe-schmitt reaction Chem. Rev. 57583

3. Glueck S M, Gumus S, Fabian W M F and Faber K 2010 Biocatalytic carboxylation Chem. Soc. Rev. 39313

4. English N J, El-Hendawy M M, Mooney D A and MacElroy J M D 2014 Perspectives on atmospheric $\mathrm{CO}_{2}$ fixation in inorganic and biomimetic structures Coord. Chem. Rev. 26985

5. Mikkelsen M, Jorgensena M and Krebs F C 2010 The teraton challenge. A review of fixation and transformation of carbon dioxide Energy Environ. Sci. 343

6. Nielsen C J, Herrmann H and Weller C 2012 Atmospheric chemistry and environmental impact of the use of amines in carbon capture and storage (CCS) Chem. Rev. 416684

7. Savile C K and Lalonde J J 2011 Biotechnology for the acceleration of carbon dioxide capture and sequestration Curr. Opin. Biotechnol. 22818

8. (a) Wang W, Wang S, Ma X and Gong J 2011 Recent advances in catalytic hydrogenation of carbon dioxide Chem. Soc. Rev. 403703

9. (a) Kondratenko E V, Mul G, Baltrusaitis J, Larrazabal G O and Perez-Ramirez J 2013 Status and perspectives of $\mathrm{CO}_{2}$ conversion into fuels and chemicals by catalytic, photocatalytic and electrocatalytic processes. Energy Environ. Sci. 63112 ; (b) Appel A M, Bercaw J E, Bocarsly A B, Dobbek H, DuBois D L, Dupuis M, Ferry J G, Fujita E, Hille R, Kenis P J A, Kerfeld C A, Morris R H, Peden C H F, Portis A R, Ragsdale S W, Rauchfuss T B, Reek J N H, Seefeldt L C, Thauer R K and Waldrop G L 2013 Frontiers Opportunities, and challenges in biochemical and chemical catalysis of $\mathrm{CO}_{2}$ fixation Chem. Rev. 1136621

10. Finn C, Schnittger S L, Yellowlees J and Love J B 2012 Molecular approaches to the electrochemical reduction of carbon dioxide Chem. Commun. 481392

11. Wu J, Huang Y, Ye W and Li Y $2017 \mathrm{CO}_{2}$ Reduction: From the Electrochemical to Photochemical Approach Adv. Sci. 41700194

12. Kondratenko E V, Mul G, Baltrusaitis J, Larrazabalc G O and Perez-Ramirez J 2013 Status and perspectives of $\mathrm{CO}_{2}$ conversion into fuels and chemicals by catalytic, photocatalytic and electrocatalytic processes Energy Environ. Sci. 63112

13. Oh Y and $\mathrm{Hu} X 2013$ Organic molecules as mediators and catalysts for photocatalytic and electrocatalytic $\mathrm{CO}_{2}$ reduction Chem. Soc. Rev. 422253

14. Shi J, Jiang Y, Jiang Z, Wang X, Wang X, Zhang S, Hanac P and Yang C 2015 Enzymatic conversion of carbon dioxide Chem. Soc. Rev. 445981

15. Arakawa H, Aresta M, Armor J N, Barteau M A, Beckman E J, Bell A T, Bercaw J E, Creutz C, Dinjus E, Dixon D A, Domen K, DuBois D L, Eckert J, Fujita E, Gibson D H, Goddard W A, Goodman D W, Keller J, Kubas G J, Kung H H, Lyons J E, Manzer L E, Marks T J, Morokuma K, Nicholas K M, Periana R, Que L,
Rostrup-Nielson J, Sachtler W M H, Schmidt L D, Sen A, Somorjai G A, Stair P C, Stults B R and Tumas W 2001 Catalysis research of relevance to carbon management: progress, challenges, and opportunities Chem. Rev. 101 953

16. Behr A 1988 Carbon dioxide as an alternative C1 synthetic unit: Activation by transition-metal complexes Angew. Chem., Int. Ed. Engl. 27661

17. Aresta M and Dibenedetto A 2007 Utilisation of $\mathrm{CO}_{2}$ as a chemical feedstock: opportunities and challenges Dalton Trans. 282975

18. Jessop P G, Ikariya T and Noyori R 1995 Homogeneous hydrogenation of carbon dioxide Chem. Rev. 95259

19. (a) Jeoung J H and Dobbek H 2007 Cabondioxide activation at the Ni, Fe-cluster of anaerobic carbon monoxide dehydrogenase Science 318 1461; (b) Parkin A, Seravalli J, Vincent K A, Ragsdale S W and Armstrong F A 2007 Rapid and Efficient electroctalytic $\mathrm{CO}_{2} / \mathrm{CO}$ interconversions by Carboxydothermus hydrogenoformans CO dehydrogenase I on an electrode J. Am. Chem. Soc. 129 10328; (c) Dobbek H, Gremer L, Kiefersauer R, Huber R and Meyer O 2002 Catalysis at air dinuclear $[\mathrm{CuSMo}(=\mathrm{O}) \mathrm{OH}]$ cluster in a $\mathrm{CO}$ dehydrogenase

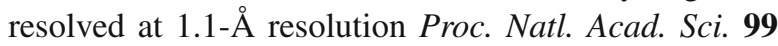
15971

20. Lindahl P A 2002 The Ni-containing carbon monoxide dehydrogenase family: Light at the end of the tunnel? Biochemistry 412097

21. Woolley P 1975 Models for metal ion function in carbonic anhydrase Nature $\mathbf{2 5 8} 677$

22. Merz K M, Hoffmann R and Dewar M J S 1989 The mode of action of carbonic anhydrase J. Am. Chem. Soc. 1115636

23. Krishnamurthy V M, Kaufman G K, Urbach A R, Gitlin I, Gudiksen K L, Weibel D B and Whitesides G M 2008 Carbonic anhydrase as a model for biophysical and physical-organic studies of proteins and protein-ligand binding Chem. Rev. 108946

24. Eriksson A E, Jones T A and Liljas A 1988 Refined structure of human carbonic anhydrase II at $2.0 \AA$ resolution Proteins 4274

25. Schrodt A, Neubrand A and van Eldik R 1997 Fixation of CO_2 by Zinc(II) Chelates in Alcoholic Medium. X-ray Structures of $\left\{[\mathrm{Zn}(\right.$ cyclen $\left.)] \_3\left(\mu \_3-\mathrm{CO} \_3\right)\right\}\left(\mathrm{ClO} \_4\right) \_4$ and [Zn(cyclen)EtOH](ClO_4)_2 Inorg. Chem. 364579

26. Tanase T, Nitta S, Yoshikawa S, Kobayashi K, Sakurai T and Yano S 1992 Spontaneous fixation of carbon dioxide in air by a nickel diamine complex: synthesis and characterization of a trinuclear nickel(II) complex with a novel hydrogen bonding system around a carbonate ligand Inorg. Chem. 311058

27. Kimura E 2001 Model studies for molecular recognition of carbonic anhydrase and carboxypeptidase Acc. Chem. Res. 34171

28. Behr A 1988 Carbon dioxide as an alternative C1 synthetic unit: Activation by transition-metal complexes Angew. Chem. Int. Ed. 27661

29. Gibson D H 1996 The ogranometallic chemistry of Carbon dioxide Chem. Rev. 962063

30. Gibson D H Carbon dioxide coordination chemistry: Metal complexes and surface-bound species. What relationship? Coord. Chem. Rev. 185335 
31. Leitner W 1996 The coordination chemistry of carbon dioxide and its relevance for catalysis: A critical survey Coord. Chem. Rev. 153257

32. Palmer D A and Vaneldik R 1983 The chemistry of metal carbonato and carbondioxide complexes Chem. Rev. 83 651

33. Kitajima N, Hikichi S, Tanaka M and Morooka $Y$ 1993 Fixation of catmospheric carbon dioxide by a series of hydroxo complexes of divalent metal ions and the implication for the catalytic role of metal ion in carbonic anhydrase. Synthesis, Characterization, and molecular structure of $[\mathrm{LM}(\mathrm{OH})] \mathrm{n}(\mathrm{n}=1$ or 2$)$ and $\mathrm{LM}$ $\left(\mu-\mathrm{CO}_{-} 3\right) \mathrm{ML}(\mathrm{M}(\mathrm{II})=\mathrm{Mn}, \mathrm{Fe}, \mathrm{Co}, \mathrm{Ni}, \mathrm{Cu}, \mathrm{Zn} ; \mathrm{L}=$ HB(3,5-iso-Pr2pz)3) J. Am. Chem. Soc. 1155496

34. Muthuramalingam S, Khamrang T, Velusamy $M$ and Mayilmurugan R 2017 Catalytic fixation of atmospheric carbon dioxide by copper(II) complexes of bidentate ligands Dalton Trans. 4616065

35. Garcia-Espana E, Gavina P, Latorre J, Soriano C and Verdejo B 2004 CO2 fixation by copper(II) complexes of a terpyridinophane aza receptor J. Am. Chem. Soc. 126 5082

36. Comba P, Gahan L R, Hanson G R, Maeder M and Westphal M 2014 Carbonic anhydrase activity of dinuclear CuII complexes with patellamide model ligands Dalton Trans. 433144

37. Massoud S S, Louka F R, Al-Hasan M A, Vicente $\mathrm{R}$ and Mautner F A 2015 Magneto-structural properties of carbonato-bridged copper(ii) complexes: fixation of atmospheric $\mathrm{CO}_{2}$ New. J. Chem. 39 5944

38. Farrugia L J, Lopinski S, Lovatt P A and Peacock R D 2001 Fixing Carbon Dioxide with Copper: Crystal Structure of $\left[\mathrm{LCu}\left(\mu-\mathrm{C} \_2 \mathrm{O} \_4\right) \mathrm{CuL}\right][\mathrm{Ph} 4 \mathrm{~B}] 2\left(\mathrm{~L}=\mathrm{N}, \mathrm{N}^{\prime}, \mathrm{N}^{\prime \prime}\right.$ Triallyl-1,4,7-triazacyclononane) Inorg. Chem. $\mathbf{4 0}$ 558

39. Angamuthu R, Byers P, Lutz M, Spek A L and Bouwman E 2010 Electrocatalytic $\mathrm{CO}_{2}$ conversion to oxalate by a copper complex Science $\mathbf{3 2 7} 313$

40. Pokharel U R, Fronczek F R and Maverick A W 2014 Reduction of carbon dioxide to oxalate by a binuclear copper complex Nature Commun. 55883
41. Takisawa H, Morishima Y, Soma S, Szilagyi R K and Fujisawa K 2014 Conversion of carbon dioxide to oxalate by $\alpha$-Ketocarboxylatocopper(II) complexes Inorg. Chem. $\mathbf{5 3} 8191$

42. (a) Yin H, Wada Y, Kitamura T and Yanagida S 2001 Photoreductive hehalogenation of halogenated benzene derivatives using $\mathrm{ZnS}$ or $\mathrm{CdS}$ nanocrystallites as photocatalysts Environ. Sci. Technol. 35 227; (b) Xie J, Li C, Zhou Q, Wang W, Hou Y, Zhang B and Wang X 2012 Large improvement in the catalytic activity due to small changes in the diimine ligands: New mechanistic insight into the dirhodium(II,II) complex-based photocatalytic H2 production Inorg. Chem. 51 6376; (c) Sun Y P, Ma B and Lawson G E 1995 Electron donor-acceptor interactions of fullerenes $\mathrm{C}_{6} \mathrm{O}$ and $\mathrm{C}_{7} \mathrm{O}$ with triethylamine Chem. Phys. Lett. 233 57; (d) Singh P K, Nath S, Bhasikuttan A C, Kumbhakar M, Mohanty J, Sarkar S K, Mukherjee T and Pal H 2008 Effect of donor orientation on ultrafast intermolecular electron transfer in coumarin-amine systems J. Chem. Phys. 129 114504; (e) Prashanthi S, Kumar P H, Wang L, Perepogu A K and Bangal P R 2010 Reductive fluorescence quenching of the photoexcited free base meso-tetrakis (pentafluorophenyl) porphyrin by amines J. Fluoresc. 20 571; (f) Kurahashi T 2015 Reverse catalase reaction: Dioxygen activation via twoelectron transfer from hydroxide to dioxygen mediated By a manganese(III) salen complex Inorg. Chem. 54 8356; (g) Gorner H 2008 Oxygen uptake after electron transfer from donors to the triplet state of nitronaphthalenes and dinitroaromatic compounds J. Photochem. Photobiol. 195235

43. Yoke J T, Weiss J F and Tollin G 1963 Reactions of triethylamine with copper(I) and copper(II) halides Inorg. Chem. 21210

44. Meyer M, Albrecht-Gary A M, Dietrich-Buchecker C O and Sauvage J P $1999 \pi-\pi$ Stacking-Induced Cooperativity in Copper(I) Complexes with Phenanthroline Ligands Inorg. Chem. 382279

45. Sanna G, Pilo M I, Zoroddu M A, Seeber R and Mosca S 1993 Electrochemical and spectroelctrochemical study of copper complexes with 1,10-phenanthrolines Inorg. Chim. Acta 208153 